\title{
Pengembangan Lembar Kerja Peserta Didik (LKPD) Kimia Berbasis Keterampilan Generik Sains
}

\section{Development of Chemistry Workbook Based on Science Generic Skill}

\author{
Rahma Sarita $^{1 *}$, Yenni Kurniawati ${ }^{1}$ \\ ${ }^{1}$ Program Studi Pendidikan Kimia FTK UIN Sultan Syarif Kasim Riau
}

\section{A B S T R A K}

Penelitian ini dilatarbelakangi karena kurangnya ketersediaan bahan ajar yang dapat membantu peserta didik dalam proses pembelajaran dan belum adanya penggunaan LKPD berbasis keterampilan generic sains. Dalam penelitian ini dikembangkan LKPD berbasis Keterampilan Generik Sains untuk mendukung pembelajaran pada materi larutan penyangga. Jenis penelitian merupakan penelitian pengembangan dengan menggunakan desain Borg and Gall, yang dilakukan di SMA Negeri 1 Tambang. Data yang diambil dalam penelitian ini yaitu berupa data angket, wawancara, dan studi pustaka. Instrumen pengumpulan data berupa data angket uji validitas dan angket uji praktikalitas. Data yang diperoleh kemudian dianalisis dengan teknik analisis deskriptif kualitatif dan deskriptif kuantitatif. Lembar Kerja Peserta Didik (LKPD) yang dihasilkan telah teruji valid dengan persentase $86,88 \%$ (sangat valid) dan teruji praktis dengan persentase $89,09 \%$ (Sangat Praktis). Dari hasil tersebut disimpulkan bahwa Lembar Kerja Peserta Didik berbasis keterampilan generik sains pada materi larutan penyangga sudah valid dan praktis sehingga dapat dilakukan uji coba selanjutnya.

\section{$A B S T R A C T$}

This research was instigated by the lack of available teaching subject that could support students in the learning process and the unavailability of the use of Science Generic Skill-based student chemistry workbook. In this research, it was designed Science Generic Skill-based student chemistry workbook to support a learning on Buffer Solution lesson. It was a Research and Development (R\&D) with Borg and Gall design, and it was administered at State Senior High School 1 Tambang. The obtained data were in the forms of questionnaire, interview, and library study. Instruments of collecting the data were validity and practicality test questionnaires. The obtained data were analyzed by using Descriptive qualitative and quantitative analysis techniques. The produced student workbook was tested, and it was valid with $86.88 \%$ percentage (very valid), and practical with $89.09 \%$ percentage (very practical). Based on these results, it could be concluded that Science Generic Skill-based student chemistry workbookonBuffer Solution lesson was valid and practical, so it could be tested further.

Kata kunci : Larutan penyangga; lembar kerja siswa; keterampilan generik sains.

Keyword : Buffer solution; student workbook; science generic skill.

I N F O A R T I K E L

Received: 15 Oct 2019,

Revised: 04 May 2020;

* coresponding author: rahmasarita179@gmail.com

Accepted: 17 Jun 2020

DOI: https://doi.org/10.22437/jisic.v12i1.7846 


\section{PENDAHULUAN}

Perangkat pembelajaran dapat berupa bahan ajar, salah satu bahan ajar yang dapat dikembangkan yaitu Lembar Kerja Peserta Didik (LKPD). LKPD adalah lembaranlembaran berisi tugas yang harus dikerjakan oleh peserta didik. Penggunaan LKPD akan membuka kesempatan seluas-luasnya kepada peserta didik untuk aktif dalam proses pembelajaran, baik secara individu maupun kelompok diskusi (Marito, Susilawati, \& Abdulah, 2016; Ruku \& Rusmini, 2019; Rahmatillah, Halim, A. \& Hasan, 2017). LKPD juga memuat kegiatan yang harus dilakukan oleh peserta didik dalam melatih kemampuan untuk memaksimalkan pemahaman dan upaya pembentukan kemampuan dasar sesuai indikator pencapaian hasil belajar yang harus ditempuh (Priyanto \& Harnoko, 1997; Auliya, Yustida, \& Ahmad, 2017). Serta LKPD juga medukung peserta didik untuk mengembangkan konsep pada proses pembelajaran (Wandari, A., Kamid, \& Maison, 2018; Indarasati \& Manoy, 2017).

Dalam proses pembelajaran, peserta didik diharapkan memiliki keterampilan dan mampu mengaplikasikannya kedalam kehidupan sehari-hari (Sayak, Sahputra, \& Lestari, 2017). Pengaplikasian tersebut belum dapat dipenuhi apabila keterampilan dasarnya belum terbentuk. Keterampilan dasar disebut sebagai keterampilan generik. Keterampilan generik merupakan salah satu keterampilan utama peningkatan kualitas sumber daya manusia diabad 21 (Zulfiani \& Octafiana, 2014). Faktor-faktor Keterampilan generik diantaranya kemampuan berkomunikasi, kejujuran dan integritas, kemampuan bekerja sama, kemampuan interpersonal dan etika. Dalam bidang sains, keterampilan generik dikenal sebagai keterampilan generik sains (KGS).

Keterampilan generik sains merupakan kemampuan intelektual hasil perpaduan atau interaksi kompleks antara pengetahuan sains dan keterampilan. Keterampilan generik sains dapat diterapkan pada berbagai bidang. Keterampilan generik sains merupakan keterampilan yang dapat digunakan untuk mempelajari berbagai konsep-konsep serta menyelesaikan berbagai masalah sains. Keterampilan generik sains merupakan keterampilan yang perlu dilatih dan dioptimalkan sejak dini, terutama pada setiap peserta didik disekolah SMA. Keterampilan generik sains juga sebagai kemampuan dan atribut untuk hidup dan bekerja. Keterampilan generik sains dapat digunakan untuk semua jenis pekerjaan, termasuk kompetensi dasar atau kemampuan kunci yang mencakup kemampuan kognitif, personal dan interpersonal. Keterampilan generik sains sangat berguna untuk melanjutkan pendidikan dan kesuksesan karier (Tawi \& Liliasari, 2014)

Berdasarkan studi awal penelitian didapatkan informasi bahwa peserta didik hanya difasilitasi buku paket dan Lembar Kerja Peserta Didik (LKPD) yang disediakan oleh pihak sekolah, belum adanya penggunaan Lembar Kerja Peserta Didik (LKPD) berbasis keterampilan generik sains yang digunakan dalam proses pembelajaran. Buku cetak dan Lembar Kerja Peserta Didik (LKPD) yang dimiliki guru belum mendukung kompetensi dasar siswa diantaranya kompetensi dalam mengembangkan keterampilan generik sains yang perlu dimiliki oleh siswa untuk dapat membantu siswa dalam menguasai konsep sains. Oleh karena diperlukan suatu bahan ajar yang dapat mempermudah peserta didik dalam memahami pembelajaran serta meningkatkan kualitas pembelajaran dalam mencapai tujuan pembelajaran kimia dan juga meningkatkan keterampilan generik sains pada peserta didik.

Maka didesain LKPD berbasis keterampilan generik sains yang didalamnya terdapat kompetensi generik dalam pembelajaran sains. Adapun manfaat kompetensi generik yaitu 1) membantu guru mengetahui apa yang harus ditingkatkan pada peserta didik dan membelajarkan peserta didik dalam cara belajar, 2) pembelajaran dengan memperhatikan konsep generik dapat digunakan untuk mempercepat pembelajaran, 3) dengan berlatih kompetensi generik peserta didik dapat mengatur kecepatan belajarnya sendiri, 4) meminimalisir miskonsepsi peserta 
didik (Nurrohman, Suyatna, A., \& Ertikanto, 2014)

LKPD berbasis keterampilan generik sains merupakan lembar kerja yang disusun dengan memperhatikan indikator-indikator yang ada pada keterampilan generik sains. Adapun indikator-indikator keterampilan generik sains yang digunakan meliputi pengamatan langsung, bahasa simbolik, hukum sebab akibat, inferensi logika dan pemodelan matematik. Oleh karena itu peneliti memandang bahwa dibutuhkan suatu Lembar Kerja Peserta Didik (LKPD) berbasis keterampilan generik sains, hal ini dikarenakan untuk memaksimalkan pengetahuan awal dari pengetahuan dan pemahaman yang dimiliki peserta didik melalui LKPD yang disusun. Maka selain itu penggunaan LKPD berbasis keterampilan generik sains ini juga ditujukan pula agar peserta didik dapat meningkatkan hasil belajar terhadap materi yang diajarkan (Rahmawaty, 2014).

Berdasarkan permasalahan dan faktafakta yang tampak di lapangan, beserta penelitian yang relevan maka peneliti tertarik untuk mengembangkan LKPD berbasis keterampilan generik sains pada materi larutan penyangga. Pengembangan LKPD ini diharapkan dapat berdampak pada peningkatan hasil belajar peserta didik. Selain itu guru juga terbantu dalam melaksanakan proses pembelajaran yang bermakna di kelas dan sebagai alternatif untuk pengajaran materi kimia lain dengan karakteristik yang sama.

\section{METODE PENELITIAN}

Penelitian ini merupakan penelitian dan pengembangan $(R \& D)$ dengan menggunakan desain perancangan media pembelajaran tipe Borg and Gall yang terdiri dari sepuluh tahapan yaitu, penelitian dan pengumpulan data (research and information collecting), perencanaan (planning), pengembangan draf produk (develop preliminary form of product), uji coba lapangan awal (preliminary field testing), revisi produk awal (main product revision), uji coba lapangan (main field testing), penyempurnaan produk hasil uji coba lapangan (operasional product revision), uji pelaksanaan lapangan (operasional field testing), penyempurnaan produk akhir (final product revision), dan diseminasi dan implementasi (dissemination and implementation).

Penelitian dilaksanakan di SMA Negeri 1 Tambang. Populasi dalam penelitian ini adalah kelas XII IPA SMA Negeri 1 Tambang yang terdiri dari 4 kelas yang berjumlah 124 peserta didik. Sampel dalam penelitian ini terdiri dari 10 peserta didik yang diambil dari salah satu kelas yang dipilih secara acak. Pada peneltian ini tidak semua tahapan pengembangannya dilaksanakan yaitu hanya sampai pada langkah revisi produk awal.

Teknik pengumpulan data menggunakan metode wawancara, angket, dokumentasi dan tes. Tes yang digunakan dalam penelitian ini adalah tes essay. Wawancara yang dilakukan termasuk jenis wawancara tidak terstruktur. Wawancara dilakukan kepada salah satu guru kimia di SMAN 1 Tambang, tujuannya untuk memperoleh informasi mengenai metode pembelajaran yang digunakan dalam proses pembelajaran kimia khususnya materi larutan penyangga. Dokumentasi dilakukan untuk mendapatkan data sekunder sekolah yakni sejarah sekolah, keadaan guru dan peserta didik, serta sarana dan prasarana yang ada di SMAN 1 Tambang. Angket yang digunakan dalam penelitian ini berupa angket ahli media, ahli materi, guru kimia dan peserta didik. Angket disusun menurut perhitungan skala lima.

Data yang diperoleh diklasifikasikan menjadi dua, yaitu data kualitatif dan kuantitatif. Data kualitatif yang berupa komentar dan saran yang dikemukakan oleh ahli media, ahli materi, guru kimia, dan peserta didik dikumpulkan untuk memperbaiki produk media pembelajaran. Data kuantitatif diperoleh dari skor yang diberikan oleh validator. Hasil persentase validitas kemudian ditafsirkan dalam pengertian kualitatif berdasarkan pada tabel 1 . 
Tabel 1. Kriteria hasil uji validasi

\begin{tabular}{ll}
\hline Interval & Kriteria \\
\hline $81 \%-100 \%$ & Sangat Valid \\
$61 \%-80 \%$ & Valid \\
$41 \%-60 \%$ & Cukup Valid \\
$21 \%-40 \%$ & KurangValid \\
$0 \%-20 \%$ & Tidak Valid \\
\hline
\end{tabular}

Produk yang dikembangkan dikategorikan valid jika persentase keidealan diatas atau sama dengan $61 \%$. Untuk hasil presentase kepraktisan juga ditafisrkan dalam pengertian kualitatif berdasarkan pada tabel 2 .

Tabel 2. Kriteria hasil uji praktikalitas

\begin{tabular}{ll}
\hline Interval & Kriteria \\
\hline $81 \%-100 \%$ & Sangat Praktis \\
$61 \%-80 \%$ & Praktis \\
$41 \%-60 \%$ & Cukup Praktis \\
$21 \%-40 \%$ & Kurang Praktis \\
$0 \%-20 \%$ & Tidak Praktis \\
\hline
\end{tabular}

Produk yang dikembangkan dikategorikan praktis jika persentase keidealan di atas atau sama dengan $61 \%$.

\section{HASIL DAN PEMBAHASAN}

Produk yang didesain dalam penelitian ini yaitu berupa Lembar Kerja Peserta Didik (LKPD) Berbasis Keterampilan Generik Sains pada Materi Larutan Penyangga. Peraturan menteri Pendidikan dan Kebudayaan Republik Indonesia nomor 87 tahun 2013 juga menyatakan bahwa Lembar Kerja Peserta Didik (LKPD) merupakan suatu bahan ajar yang harus dikembangkan khususnya dalam dunia pendidikan. LKPD ini dikembangkan oleh peneliti agar dapat menjadi bahan ajar yang dapat membantu guru dalam proses pembelajaran dan sebagai salah satu sumber belajar bagi peserta didik baik di kelas maupun di rumah. LKPD Berbasis Keterampilan Generik Sains pada Materi Larutan Penyangga ini dikembangkan dengan menggunakan prosedur pengembangan menurut Borg and Gall yang disederhanakan sesuai kebutuhan penelitian menjadi lima tahap. Data hasil setiap tahapan yang dilakukan adalah sebagai berikut.

\section{Tahap Pengumpulan Data (Research and Information Collecting)}

Tahap pengumpulan data sangat penting dilakukan untuk mengetahui kebutuhan peserta didik terhadap produk yang dikembangkan. Tahap pengumpulan data dilakukan dengan cara studi lapangan dan studi pustaka.

\section{Studi Lapangan}

Studi lapangan dilakukan dengan cara melakukan analisis kurikulum dan analisis ketersediaan media pembelajaran di lapangan. Pada tahap ini peneliti melakukan analisis terhadap Kompetensi Inti (KI) dan Kompetensi Dasar (KD) pada kurikulum 2013. Dari hasil analisis, materi larutan penyangga cocok dengan keterampilan generik sains karena keterampilan generik sains merupakan salah satu kompetensi yang harus dicapai pada materi larutan penyangga. Selain itu materi larutan penyangga juga banyak memiliki relevansi dengan situasi nyata dan memiliki keterkaitan dengan pengetahuan penting lainnya sehingga sesuai dengan kriteria pemilihan basis keterampilan generik sains.

Peneliti juga melakukan analisis terhadap peserta didik dan guru yang dilakukan melalui proses wawancara. Hasil wawancara peserta didik diperoleh informasi bahwa peserta didik belum menguasai kemampuan generik sains. Peserta didik juga mengatakan bahwa jarang menemui LKPD yang disertai dengan pembahasan kemampuan umum dalam sains dan bertindak berdasarkan pengetahuan sains. Selain itu, wawancara dengan guru didapatkan hasil bahwasanya bahan ajar yang digunakan di sekolah tersebut berupa buku teks dan soalsoal tanpa adanya indikator-indikator untuk melatih keterampilan generik sains peserta didik 


\section{Studi Pustaka}

Studi pustaka dilakukan dengan cara mengumpulkan informasi dari jurnal maupun buku yang berkaitan dengan desain dan uji coba Lembar Kerja Peserta Didik (LKPD) Berbasis Keterampilan Generik Sains. Hal ini selaras dengan peraturan menteri Pendidikan dan Kebudayaan Republik Indonesia nomor 87 tahun 2013 yang menyatakan bahwa Lembar Kerja Peserta Didik (LKPD) merupakan suatu bahan ajar yang harus dikembangkan khususnya dalam dunia pendidikan.

\section{Tahap Perencanaan (Planning)}

Ada beberapa hal yang dilakukan pada tahap perencanaan yaitu menyesuaikan standar kompetensi dan kompetensi dasar serta silabus berdasarkan kurikulum 2013. Produk dari penelitian ini berupa LKPD berbasis keterampilan generik sains yang dirancang pada materi larutan penyangga yang dipelajari di kelas XI KD 3.12 dan 4.12. Komponen dari produk ini terdiri dari tiga bagian yaitu: (1) Pendahuluan terdiri dari: cover, kata pengantar, daftar isi, Kompetensi Inti (KI), Kompetensi Dasar (KD), indikator dalam pembelajaran, tujuan pembelajaran, materi prasyarat, deskripsi singkat, tahapan keterampilan generik sains, peta konsep, petunjuk penggunaan LKPD, (2) Bagian isi yang terdiri dari tiga kegiatan pembelajaran. Kegiatan 1: sifat larutan penyangga, kegiatan 2: $\mathrm{pH}$ larutan penyangga, kegiatan 3: peranan larutan penyangga dalam tubuh makhluk hidup. dan (3) bagian penutup berisi rangkuman, glosarium dan daftar pustaka.

\section{Tahap Pengembangan Draf Produk (Develop Preliminary Form of Product)}

Setelah perencanaan produk dilakukan maka langkah selanjutnya adalah pengembangan draf produk. Bagian-bagian dari pengembangan produk LKPD berbasis keterampilan generik sains pada materi larutan penyangga adalah sebagai berikut:

Bagian pendahuluan, bagian ini terdiri atas cover, kata pengantar, daftar isi, Kompetensi Inti (KI), Kompetensi Dasar
(KD), indikator dalam pembelajaran, tujuan pembelajaran, materi prasyarat, deskripsi singkat, tahapan keterampilan generik sains, peta konsep, petunjuk penggunaan LKPD. Bagian sampul depan (cover) didesain dengan background senada dengan seluruh tampilan background LKPD dan memuat gambar yang berhubungan dengan konsep larutan penyangga. Pada bagian ini tersedia kotak identitas kepemilikan untuk menuliskan pemilik LKPD yakni peserta didik. Kata pengantar, daftar isi, Kompetensi Inti (KI), Kompetensi Dasar (KD), indikator dalam pembelajaran, tujuan pembelajaran, materi prasyarat, deskripsi singkat, tahapan keterampilan generik sains, peta konsep, petunjuk penggunaan LKPD ditulis sesuai kaidah penulisan bahasa Indonesia dengan ejaan yang disempurnakan (EYD)

Bagian isi, yaitu berisi materi-materi yang ditujukan untuk mencapai indikator pencapaian kompetensi yang dibuat. Berdasarkan indikator yang disusun maka LKPD yang dikembangkan terdapat tiga kegiatan belajar yaitu: 1) sifat larutan penyangga, 2) $\mathrm{pH}$ larutan penyangga, 3) peranan larutan penyangga dalam tubuh makhluk hidup. Pada setiap kegiatan pembelajaran diberikan sub materi, kompetensi dasar, indikator dan tujuan pembelajaran. Materi-materi pelajaran disajikan dalam lima indikator keterampilan generik sains yakni pengamatan langsung, inferensi logika, hubungan sebab-akibat, pemodelan matematik, bahasa simbolik. Bagian penutup, bagian ini terdiri atas rangkuman, glosarium dan daftar pustaka.

Pada tahap pengembangan draf produk peneliti menghasilkan sebuah produk berupa lembar kerja peserta didik berbasis keterampilan generik sains yang sudah direvisi berdasarkan masukan dari para ahli, yaitu ahli desain media dan ahli materi pembelajaran.

\section{Ahli Desain Media}

Validasi produk oleh ahli desain media dilakukan dengan menunjukkan dan menjelaskan tentang produk media 
pembelajaran yang dikembangkan yakni berupa lembar kerja peserta didik berbasis keterampilan generik sains kepada ahli desain media pembelajaran yaitu dosen pendidikan kimia UIN SUSKA Riau. Berdasarkan hasil validasi ahli media, produk ini layak digunakan sebagai alternatif media pembelajaran disekolah.

Tabel 3. Hasil validasi oleh ahli desain media berdasarkan komponen pada indikator

\begin{tabular}{|c|c|c|c|}
\hline Indikator & Skor Penilaian & Nilai Validasi & Kriteria \\
\hline Penggunaan Huruf dan Tulisan & 34 & $85 \%$ & Sangat valid \\
\hline LKPD Berpenampilan Menarik & 21 & $92 \%$ & Sangat valid \\
\hline Jumlah Keseluruhan & 55 & $84,61 \%$ & Sangat valid \\
\hline
\end{tabular}

Dari hasil validasi oleh ahli desain media, didapatkan hasil bahwa media pembelajaran berupa lembar kerja peserta didik berbasis keterampilan generik sains sudah sangat valid dengan kategori layak untuk diuji cobakan, karena persentase kevalidan sebesar $84,61 \%$ berada pada rentang $81 \%$ sampai $100 \%$ sehingga lembar kerja peserta didik tidak memerlukan revisi. Namun komentar dan saran dari ahli media pembelajaran dijadikan bahan perbaikan untuk menyempurnakan lembar kerja peserta didik yang didesain. Adapun saran dan masukan dari ahli media yaitu perbaiki siluet agar lebih menarik, perhatikan penulisan font, spasi, tab, huruf besar dan kecil, perhatikan design gambar, layout, konsisten terhadap jenis font, ukuran font, dan warna font, perhatikan penggunaan bahasa Indonesia yang baik dan benar dan perbaiki pada beberapa penulisan yang salah.

\section{Ahli Materi Pembelajaran}

Validasi produk oleh ahli materi pembelajaran dilakukan dengan menunjukkan dan menjelaskan tentang produk media pembelajaran berupa lembar kerja peserta didik kepada dua ahli materi pembelajaran yaitu guru mata pela-jaran kimia di SMA Negeri 1 Tambang.

Tabel 4. Hasil validasi oleh ahli materi pembelajaran berdasarkan komponen pada indikator

\begin{tabular}{lcclc}
\hline $\begin{array}{l}\text { Variabel } \\
\text { Validasi }\end{array}$ & Indikator & $\begin{array}{c}\text { Nilai } \\
\text { Validitas }\end{array}$ & Kriteria & $\begin{array}{c}\text { Kriteria Tiap } \\
\text { Variabel Validitas }\end{array}$ \\
\hline Syarat & $\mathrm{A}$ & $90 \%$ & Sangat valid & \\
Didaktif & $\mathrm{B}$ & $80 \%$ & Sangat valid & $87,14 \%$ (Sangat \\
& $\mathrm{C}$ & $90 \%$ & Sangat valid & valid) \\
& $\mathrm{D}$ & $85 \%$ & Sangat valid & \\
\hline Syarat & $\mathrm{E}$ & $90 \%$ & Sangat valid & \\
Konstruksi & $\mathrm{A}$ & $90 \%$ & Sangat valid & \\
& $\mathrm{B}$ & $85 \%$ & Sangat valid & \\
& $\mathrm{C}$ & $95 \%$ & Sangat valid & \\
\hline
\end{tabular}


Persentase kevalidan LKPD berbasis keterampilan generik sains oleh ahli materi pembelajaran ini sebesar $89,16 \%$ berada pada rentang $81 \%$ sampai $100 \%$ sehingga lembar kegiatan peserta didik dapat dinyatakan sangat valid dan dikategorikan layak untuk diujicobakan ke sekolah.

\section{Tahap Uji Coba Lapangan Awal (Preliminary Field Testing)}

Pada tahap uji coba lapangan awal, lembar kerja peserta didik yang telah divalidkan oleh para ahli kemudian diujicobakan ke sekolah. Uji coba dilaksanakan di SMA Negeri 1 Tambang yaitu kepada 1 orang guru kimia dan 10 orang peserta didik. Hasil uji coba ini dipakai untuk mengetahui praktikalitas produk yang didesain. Hasil uji coba diperoleh melalui pengisian angket guna untuk mengetahui respon dari guru kimia dan peserta didik terhadap lembar kerja peserta didik yang dikembangkan. Angket uji coba ini diisi oleh guru kimia dan peserta didik setelah membaca dan memahami lembar kerja peserta didik berbasis keterampilan generik sains yang dikembangkan.

\section{Uji Praktikalitas Guru}

Uji praktikalitas dilakukan pada satu orang guru kimia SMA Negeri 1 Tambang Selain pengisian angket uji praktikalitas, guru juga memberikan saran dan kritikan demi perbaikan produk yang dikembangkan. Peneliti melakukan revisi terhadap desain produk yang dikembangkan berdasarkan masukan-masukan tersebut. Adapun saran atau masukan untuk perbaikan tersebut ditunjukkan dalam tabel 5 sedangkan hasil uji praktikalisasi dapat dilihat seperti pada tabel 6 .

Tabel 5. Saran guru mata pelajaran terhadap LKPD berbasis keterampilan generik sains

\begin{tabular}{clc}
\hline Validator & Saran & Perbaikan \\
\hline & $\begin{array}{l}\text { Warna LKPD dipercantik sehingga bisa menarik peserta didik } \\
\text { untuk mempelajarinya }\end{array}$ & \\
Guru Mata & $\begin{array}{l}\text { Isi materi didalam LKPD disusun lebih terorganisis dalam } \\
\text { Pelajaran } \\
\text { dandikator keterampilan generik sains berdasarkan analisis KI } \\
\end{array}$ & $\begin{array}{c}\text { Sudah } \\
\text { diperbaiki }\end{array}$ \\
& Keterangan rumus dalam LKPD kurang lengkap & \\
\hline
\end{tabular}

Tabel 6. Hasil penilaian praktikalitas oleh guru kimia berdasarkan indikator

\begin{tabular}{lccl}
\hline Indikator & $\begin{array}{c}\text { Skor } \\
\text { Penilaian }\end{array}$ & $\begin{array}{c}\text { Nilai } \\
\text { Praktikalitas }\end{array}$ & Kriteria \\
\hline Organisasi LKPD & 5 & $100 \%$ & Sangat Praktis \\
Kebenaran Konsep & 8 & $80 \%$ & Praktis \\
Kesesuaian Materi & 14 & $93,33 \%$ & Sangat Praktis \\
Muatan Kurikulum 2013 & 13 & $86,66 \%$ & Sangat Praktis \\
Tingkat Keterlaksanaan Soal & 8 & $80 \%$ & Praktis \\
Evaluasi Belajar & 4 & $80 \%$ & Praktis \\
Kejelasan Kalimat dan Tingkat & 23 & $92 \%$ & Sangat Praktis \\
Keterbacaan & \multicolumn{2}{c}{} & \\
Tampilan Fisik LKPD & 23 & $92 \%$ & Sangat Praktis \\
\hline \multicolumn{1}{c}{ Hasil } & $\mathbf{9 8}$ & $\mathbf{8 9 , 0 9 \%}$ & \\
\hline
\end{tabular}


Hasil analisis terhadap angket uji praktikalitas yang diperoleh dari satu orang guru kimia di SMA Negeri 1 Tambang adalah 98 dengan skor maksimal 110 maka didapatkan persentase sebesar $89,09 \%$ artinya media pembelajaran berupa lembar kerja peserta didik dalam kategori sangat praktis atau layak untuk diujicobakan ke peserta didik SMA dalam proses pembelajaran laju reaksi di sekolah.

\section{Hasil Respon Peserta Didik}

Lembar Kerja Peserta Didik (LKPD) berbasis keterampilan generik sains yang telah divalidasi dan telah di uji praktikalitas oleh guru SMAN Negeri 1 Tambang, selanjutnya dilakukan uji coba kepada 10 orang peserta didik kelas XII IPA 1 untuk melihat efektifitas LKPD berupa respon siswa terhadap LKPD ini. Angket uji coba respon peserta didik berupa angket semi terbuka yang terdiri dari 5 pertanyaan.

Berdasarkan data dari hasil uji coba terbatas, peserta didik menganggap bagian yang paling sulit dipahami dalam LKPD ini adalah soal essay. Bagian yang paling menarik dalam LKPD ini adalah bagian cover sedangkan bagian yang kurang menarik adalah soal-soal latihan. Mayoritas peserta didik setuju bahwa LKPD ini dapat mendukung proses pembelajaran dan semua peserta didik berpendapat bahwa LKPD ini dapat menyadarkan peserta didik mengenai keterampilan generik sains itu perlu di asah terutama di mata pelajaran kimia khususnya pada materi larutan penyangga. Namun LKPD ini memiliki kekurangan yaitu kurangnya bagian variasi warna sehingga perlu ditambahkan untuk menimbulkan minat baca peserta didik.

Pembelajaran berbasis keterampilan generik sains berpengaruh positif terhadap hubungan antara peserta didik dengan dunia nyata, mendorong peserta didik untuk lebih aktif, kreatif, berpikir kritis dalam memberikan solusi pada suatu pokok permasalahan di lingkungan sekitar (Nurrohman, Suyatna, A., \& Ertikanto, 2014). Peserta didik belajar lebih memahami suatu topik secara mendalam jika dibandingkan dengan peserta didik belajar dengan metode konvensional.

\section{Tahap Revisi Produk Awal (Main Product Revision)}

Tahap revisi produk awal ini dilakukan untuk menghasilkan produk akhir yaitu LKPD Kimia Berbasis Keterampilan Generik Sains pada Materi Larutan Penyangga. Setelah melakukan beberapa rangkaian uji validasi dari para ahli dan uji respon dari guru dan peserta didik, hasil uji validasi maupun respon sudah bagus meskipun masih ada beberapa saran untuk kedepannya yang belum bisa peneliti lakukan. Untuk itu diperlukan penelitian lebih lanjut untuk menyempurnakan LKPD ini dan penelitian lainnya untuk mengetahui pengaruh serta efektivitas LKPD kimia berbasis keterampilan generik sains pada materi larutan penyangga sebagai bahan ajar pendukung di sekolah dengan harapan LKPD ini dapat menjadi alternatif bahan ajar bagi peserta didik pada materi larutan penyangga.

\section{KESIMPULAN}

Lembar Kerja Peserta Didik (LKPD) kimia berbasis keterampilan generik sains yang telah dikembangkan dinyatakan valid oleh ahli desain media dan ahli materi pembelajaran dengan kategori sangat valid yaitu dengan persentase $86,88 \%$. Hal ini terlihat dari persentase rata-rata analisis angket ahli desain media dan ahli materi pembelajaran berturut-turut yaitu $84,61 \%$ dan 89,16\%. Lembar Kerja Peserta Didik (LKPD) kimia berbasis keterampilan generik sains yang didesain dinyatakan praktis oleh guru kimia dengan persentase $89,09 \%$ dan mendapat respon yang baik dari peserta didik. 


\section{DAFTAR RUJUKAN}

Auliya, A., Yustida, \& Ahmad, D. (2017). Pengembangan lembar kerja peserta didik (LKPD) berbasis pendekatan konstruktivisme pada materi sistem pencernaan makanan dan bahan kimia dalam kehidupan kelas VIII SMP. Jurnal Online Mahasiswa Fakultas Pendidikan dan Ilmu Keguruan Universitas Riau, 4(1), 114.

Indarasati, N. A. \& Manoy, J. T. (2017). pengembangan lembar kerja peserta didik (LKPD) berbasis literasi matematika pada materi pokok statistika. Jurnal Ilmiah Pendidikan Matematika, 2(6), 203-208.

Marito, S., Susilawati, B., Abdullah. (2016). Pengembangan lembar kegiatan peserta didik (LKPD) berorientasi pendekatan saintifik pada pokok bahasan larutan asambasa kelas XI SMA. Jurnal Online Mahasiswa Fakultas Keguruan dan Ilmu Pendidikan, 3(2), 1-10.

Nurrohman, Suyatna, A., \& Ertikanto, C. (2014). Pengembangan lembar kerja siswa (LKS) berbasis keterampilan generik sains (KGS) materi tekanan. Jurnal Pembelajaran Fisika, 2(3), 55-66.

Priyanto \& Harnoko. (1997). Perangkat pembelajaran, Jakarta: Depdikbud.

Rahmatillah, Halim, A. \& Hasan, M. (2017). Pengembangan lembar kerja peserta didik berbasis keterampilan proses sains terhadap aktivitas pada materi koloid. Jurnal IPA \& Pembelajaran IPA, 1(2), 121-130.
Rahmawaty. (2014). Efektifitas penggunaan lembar kerja siswa (LKS) dalam meningkatkan hasil belajar siswa pada mata pelajaran IPS Geografi di kelas VIII SMP Negeri 6 Pasangkayu. Geo Tandulako.

Ruku, E. C., \& Rusmini. (2019). Development of student work sheet based on softskill on colloid materials class XI High School. Journal of Chemistry Education Reasearch, 3(1), 22-28.

Sayak, S. M. L., Sahputra, R., \& Lestari, I. (2017). Keterampilan generik sains siswa SMA pada praktikum sifat koligatif larutan. Jurnal Pendidikan dan Pembelajaran Khatulistiwa, 6(3).

Tawi, M. \& Liliasari. (2014). Keterampilan-keterampilan sains dan implementasinya dalam pembelajaran IPA. Makassar: Badan Penerbit UNM.

Wandari, A., Kamid, \& Maison. (2018). Pengembangan lembar kerja peserta didik (LKPD) pada materi geometri berbasis budaya jambi untuk meningkatkan kreativitas siswa. Edumatika-Jurnal Riset Pendidikan Matematika, 1(2).

Zulfiani \& Octafiana, H. (2014). Profil keterampilan generik sains siswa SMA pada model pembejaran inkuiri terstruktur (structured inquired) konsep difusi dan osmosis. Jurnal UIN Sultan Syarif Hidayatullah 